\title{
Analysis of Posters for Informing the Population via Social Media during Covid-19: Ukrainian Network
}

\section{Аналіз постерів, що використовуються для інформування населення через соціальні мережі під час Covid-19: Українська мережа}

\section{Daniil Shmatkov ${ }^{1}$}

Ph.D. in Pedagogy,

Associate professor,

Senior research associate

\author{
Даніїл Шматков ${ }^{1}$ \\ кандидат педагогічних наук, \\ доцент, \\ старший науковий співробітник
}

\footnotetext{
E-mail: d.shmatkov@uipa.edu.ua https://orcid.org/0000-0003-2952-4070

Scopus Author ID: 57211802903
}

María Luisa Zagalaz-Sánchez ${ }^{2}$

Ph.D., Professor
Марія Луіса Загалас-Санчес ${ }^{2}$ доктор філософії, професор

E-mail: lzagalaz@ujaen.es https://orcid.org/0000-0001-6044-8569

Scopus Author ID: 42561930100

Javier Cachón-Zagalaz ${ }^{2}$

Ph.D., Professor
Хав'єр Кашон-Загалас 2

доктор філософії, професор

E-mail: jcachon@ujaen.es https://orcid.org/0000-0001-5085-0423

Scopus Author ID: 55634498700

${ }^{1}$ Scientific and Research Institute of Providing Legal Framework for the Innovative Development of the National Academy of Legal Sciences of Ukraine $\triangle$ Chernyshevskaya, 80 Str., Kharkiv, Ukraine, 61002
${ }^{1}$ Науково-дослідний інститут правового забезпечення інноваиійного розвитку НАПН України вул. Чернишевська, 80, м. Харків, 61002 
Аналіз постерів, що використовуються для інформування...

${ }^{2}$ University of Jaén (Spain)

Campus Las Lagunillas s/n, Jaén, 23071
2 Університет Хаен (Іспанія)

Кампус Лас-Лагунільяс, з/п, м. Хаен, Іспанія, 23071

Original manuscript received March, 31, 2020

Revised manuscript accepted October, 07, 2021

\begin{abstract}
Objective. This study aims to determine the extent to which psycholinguistic variables are included in the analysis of the quality of directive posters on social media during Covid-19.

Methods. The methods used in the study include analysis of the relevant scientific literature on the identification of psycholinguistic categories and variables relevant to the study; expert assessment of qualitative parameters of posters published on Facebook by official organizations; methods of descriptive statistics.

Results. The analysis of 298 unique works conducted through Ukrainian network on Facebook revealed that the overall average quality of the publications is on the borderline between medium and high levels - 69.3\% (by text parameters $-70.0 \%$, graphic parameters $-68.6 \%$ ).

Conclusions. The study revealed that psycholinguistic variables such as readability, imageability, concreteness, conceptual familiarity, semantic size, name agreement, image agreement, visual complexity, typicality, image variability, authenticity of texts, processing fluency, etc. penetrate deeply related research on the creolized texts in various forms and interpretations. The quality of the posters on Facebook made by the official institutions operating in the field of health care is at the borderline between medium and high levels. These indicators are most in need of improvement on text parameters such as "Emphasis" and "Call to action", as well as on graphical parameters such as "Presence of interactive graphic links" and "Understandability of illustration message without text".
\end{abstract}

Key words: Covid-19, social media, posters, didactic reduction, creolized text, psycholinguistic variables.

\title{
Introduction
}

Prompt communication on any developments of the outbreak from the authorities and the media, in combination with up-to-date research on the new virus Covid-19 by the science community altogether provide reliable sources of information (La et al., 2020).

There is high prevalence of mental health problems, which are positively associated with frequent social media exposure during 
the COVID-19 outbreak (Gao et al., 2020). Fabricated news and misinformation about COVID-19 have proliferated widely recently (Bavel et al., 2020). On the other hand, effective reporting on the coverage of the virus and precautionary training on social media can mitigate the dangerous effects of Covid-19 (Zhou et al., 2020). Social networks are an extremely effective mechanism for disseminating information about the virus (Cinelli et. al., 2020), including useful information, as well as rumors and speculation (Garrett, 2020). To find the most reliable information, users will rather study the publications on the official websites of specialized institutions. However, in order to maintain credibility and provide users with clear information and instructions, such publications must meet certain requirements, which will be discussed in the next sections.

Social media should support public health responses both in preparedness and controlling the outbreak by joining together with authorities in providing consistent, simple, and clear messages (Hopman, Allegranzi \& Mehtar, 2020). Moving beyond the traditional laboratory research in psycholinguistics and increasing the diversity of approaches that is the-state-of-the-art, although the traditional approach remains dominant (Speed, Wnuk \& Majid, 2018). The study of social media provides important data for the psycholinguistic field of knowledge (Herdağdelen \& Marelli, 2017; Purohit et al., 2015).

From the field of psycholinguistics, it is known that "pictures are often used in studies on memory, perception, and language; normative data are thus needed for such visual stimuli" (Ghasisin et al., 2015) and common types of human intelligence tasks include identifying images (Enochson \& Culbertson, 2015). Images are useful material for related research (Snodgrass \& Vanderwart, 1980). The study of communication in various modalities is one of the subjects of psycholinguistics (Cutler, 2017).

When developing informational and/or training materials it is extremely important to take into account users' experience (conceptual familiarity, typicality, etc. in terms of psycholinguistics). Measuring visual activity, scientists have concluded that the less the users are familiar with the subject area, the lower the speed of their orientation in the information provided (Blinnikova \& Ishmuratova, 2019). For example, modern marketing campaigns, web design, etc. are built on that aspect. Psycholinguistic studies of various information materials 
in a complex of verbal and visual interactions help to reveal the effectiveness of communication (Percy, 1992).

Moving away from traditional laboratory settings, psycholinguists can enrich the understanding of the use of language in all of its varied contexts (Speed, Wnuk \& Majid, 2018).

Thus, this study aims to determine the extent to which psycholinguistic variables are included in the analysis of the quality of directive posters on social media during Covid-19.

\section{Adherence to Ethical Standards}

The authors did not receive financial support from any organization to conduct their research. The authors do not have any financial or property interests concerning the materials presented in this article.

\section{Methods}

The methods used in the study include analysis of the relevant scientific literature on the identification of psycholinguistic categories relevant to the study; analysis of posters published on Facebook; expert assessment of qualitative parameters of posters published on Facebook by The World Health Organization Country Office in Ukraine (WHOU), Ministry of Health of Ukraine (MHU), and Public Health Centre of Ukraine (PHCU); methods of descriptive statistics (determination of averages, weighted averages, correlation analysis, substantiation of the reliability of research findings etc.).

The assessment was conducted with the participation of three experts in the fields of education, psychology, psycholinguistics, health and UX design. The study covers the analysis of unique publications (educational and informational posters on Covid-19), produced by WHOU (168 publications), MHU (65 publications) and PHCU (65 publications) which were published in 2020. Meanwhile, we divided the publications into two groups - the first included publications made before 25 March (130 publications) and the second - within the period from 25 March to 25 May (168 publications). On March 25, a state of emergency was declared in Ukraine and corresponding strict quarantine restrictions were imposed. Prior to this date, there had been a slight 
increase in cases of disease in the country. On May 25, the government began significantly easing quarantine restrictions.

The study carried out an expert assessment (Evlanov \& Kutuzov, 1978), according to which the consolidated rank (poor, satisfactory, good) of posters in accordance with each of the criteria was determined. The parameters under study were assessed at "low", "medium" or "high" levels, in percentage. Using a 3-point scale is a relevant method for the psycholinguistic study of pictures (Bonin et al., 2003). The results were processed in Microsoft Excel: averages and weighted averages were determined, a correlation analysis was conducted between the sequence of publication and the quality of the publications, Kendall rank correlation coefficient for the expert assessment was determined, and chi-squared tests were conducted.

\section{Research Context}

The quality parameters for determining the quality of posters on social media include the following criteria:

(i) Text parameters: (1) Presence of text; (2) Didactic reduction; (3) Readability; (4) Call to action; (5) Emphasis; (6) Structuring and systematization; (7) Correspondence between headline and main text; (8) Absence of obvious grammatical and stylistic errors; (9) Text color variety; (10) Absence of non-clickable links;

(ii) Graphical parameters: (1) Graphics color harmony; (2) Color diversity; (3) Color balance; (4) Presence of interactive graphic links; (5) Presence of illustrations; (6) Rational correspondence between illustration and text proportions; (7) Understandability of illustration message without text; (8) A rational number of illustrations relative to text; (9) Correspondence between headline and illustration; (10) Standardization of illustrations.

Creolized texts are an important part of life of modern society; they are created to form ideas, images and a special relationship to the world or a subject / object, which is mediated by the individual characteristics of a person (Lebedeva \& Annenkova, 2018). Achieving this goal is possible by influencing human consciousness and perception 
by various psychological, psycholinguistic methods and other ways, depending on the specific task (Lebedeva \& Annenkova, 2018).

Quantitative research of various texts on social networks is in the area of interest for psycholinguistics (Herdağdelen \& Marelli, 2017; Purohit et al., 2015; Sterling et al., 2020). The criterion "Presence of text" means that text (and numbers) describing its content is displayed in the poster. The criterion "Didactic reduction" in this context means the amount of background information deleted and the amount of principal information preserved (Shmatkov et al., 2019).

Given that the recipients of the information about Covid-19 are people of all ages, genders and levels of intellectual development, approaches to publications should ensure maximum adaptability to different target groups and cognitive simplicity of handling of information. In this regard didactic reduction methods, which are widely implemented in science, provide effective content distribution and cognitive load reduction when working with it (Prajayanti, et al, 2015), increase understanding and accelerate access to key aspects of the content (Shmatkov, 2016). Didactic reduction is one of the most effective approaches to information transfer (Lendzian \& Körner, 2018).

Many scientific papers (Biran, Brody \& Elhadad, 2011; Maier \& Budke, 2016, etc.) are devoted to the importance of text simplification in order to reduce the cognitive complexity of handling them. It is well-known that such posters should be characterized by maximum didactic reduction (Krüger \& Mannebach, 2019). For example, concreteness affects the ability to recognize words and understand texts (Paetzold \& Specia, 2016). This category simultaneously belongs to the subject areas of psycholinguistics and didactic reduction. Here we evaluated the rational filling of the posters with text, its amount, the possibility of discarding unnecessary background information.

A significant number of scientific papers are devoted to ensuring the text readability. The text readability is assessed by various indicators, such as ARI, Coleman-Liau, Flesch fog index, SMOG, Gunning, Dale-Chall, Spachi, LIX and other alternatives (Mohammadi \& Khasteh, 2019). Most methods take into account the complexity and uniqueness of sentences and words in quantitative terms, words in a sentence or letters in a word, respectively (Berger et al, 2020). In the study presented, the above-mentioned characteristics, as well as presentation of information in the language of the target audience were included 
into the "Didactic reduction" criterion. And the "Readability" criterion was used to assess the font size (Ali et al., 2013; Grobeln \& Michalski, 2015; Rello, Pielot \& Marcos, 2016), while the font style is irrelevant.

According to psychological research (Yang, Huang \& Shanks, 2018), people make broader judgments about memorization for large words than for words with a small font size, even though font size does not affect memory retention. The effect is also important because it highlights the process of dissociation between metacognitive judgments about memory and memory performance itself. Thus, in the context of the study, the font size was assessed by the "Readability" criterion (in accordance with the above-mentioned sources, the text size on the posters should be at least approximately 18, i.e., be readable).

Call to action is one of the most important components of user experience matching. Using the directive function of language, an advisor can hope that the activity can be carried out effectively (Rahman \& Amri, 2019) by a performer.

Well-designed free open access educational material should generalize key information in a clear, actionable format, while paired with social media-powered promotion using social networks (Chan et al., 2020). Focusing on the most significant points is an important aspect of simplifying the perception of information, because eye movements are acts of redistribution of attention at a time when the process of visual identification of objects interacts with verbal linguistic subsystems of the brain (Ware, 2019). Structuring and systematization of text significantly reduces cognitive load (Sweller et al., 1990), so that criterion is also selected for the analysis.

One of the components of visual complexity is text color variety that entails the use of two or three text colors to reduce the cognitive load of the user (Debernardis et al., 2013; Qiu et al., 2018). Parameter such as "Correspondence between headline and main text" and "Absence of obvious grammatical and stylistic errors" affect the reader's attitude to the publication and the authority of the source. In addition, psycholinguistic studies indicate that this parameter significantly affects text recognition (Altmann, 2001).

Absence of non-clickable links is the standard of user experience; furthermore, it is well-known that manual information search significantly reduces the effectiveness of its perception (Gao, Liu \& Paas, 2016). 
In the presented context, the graphical parameters form the complex assessment in conjunction with the textual parameters, therefore, psycholinguistics aspects here are complemented by interdisciplinary connections. Now we describe the list of criteria related to graphics.

One of the effective approaches applied in analysis of creolized texts is the level of the expressiveness of the information context (Purohit et al., 2015). Psycholinguistic research explores image metadata (Kastner et al., 2020). Visual complexity is a variable of psycholinguistic research (Moreno-Martínez, Montoro \& Laws, 2011).

Images are a very powerful way of representing sentences and other verbal material, it seems irrefutable that sentences can be memorized as images (Johnson-Laird, 1974). The color of images increases the accuracy of object identification (Laws \& Hunter, 2006) and their naming (Oliva \& Schyns, 2000).

For the "Graphics color harmony" criterion, we analyzed the compliance of the poster design with the requirements of contrast preservation through the use of analogue, complementary, triad or contrast colors. Approximately three primary colors for the overall background and palette of the main blocks are the best solution from the user experience (Qiu et al., 2018). Color balance refers to the choice of the primary, the secondary and the third color in approximate proportions or 60-30-10 (Ferris \& Zhang, 2016), 70-25-5 (Kobayashi, 2009) or 74-22-4 (Qiu et al., 2018), etc., which also corresponds to the user experience.

The need to develop interactive graphic links (for example, QR codes) in web design is confirmed by psychological studies (Shin, Jung \& Chang, 2012). The studies show that interactive graphic links creation meets the requirement of interactivity, because interactivity is a key behavioral precursor to the use of QR codes.

It should be noted that, taking into account human sensory capabilities, important information should always be presented in such a way that important data elements and data patterns can be quickly perceived, so the "Presence of graphic support of textual information" is an essential criterion. Sensory perception does not require specific training, thereby presenting the idea with the aid of an image provides less cognitive load for its processing (Ware, 2019). In this regard the criterion "Rational correspondence between illustration and text 
proportions" is introduced. According to the criterion, the most effective solution is size equality of the illustration block and the text block. It is also considered a good solution when the illustration block is of larger size than the text.

The relationship between image and text is also a subject of research in psycholinguistics (Kastner et al., 2020). Image and text matching are a potential moderator of language effects in memory (Luna \& Peracchio, 2001). The criteria such as "Understandability of illustration message without text", "Rational number of illustrations relative to text" (one message - one illustration), and "Correspondence between headline and illustration" were also introduced in order to more accurately determine whether illustrated posters reduce the user's cognitive load.

The last parameter is "Standardization of illustrations" unambiguity of associations and interpretations that they convey. In psycholinguistics, typicality reflects the degree of representativeness of a concept in its category (Moreno-Martínez, Montoro \& Laws, 2011). The interaction of the growing nervous system with everyday reality leads to a more or less standard visual system. This, in turn, leads to a situation when people develop and understand the same visual systems (with surfaces, textures, colors, shapes and other properties), regardless of cultural environment (Ware, 2019).

\section{Results}

As a result of the analysis of 298 graphic-text unique publications made by WHOU, MHU, PHCU, and 5960 evaluations according to the defined criteria were carried out. Detailed statistical reports are published in the Mendeley Data repository and are available for review (Shmatkov, 2021).

The findings are presented in Table 1.

The overall average of the quality of graphic and text publications is on the borderline between medium and high levels and accounts for $69.3 \%$ (by text parameters $-70.0 \%$, by graphics $-68.6 \%$ ).

Presence of interactive graphic links is at a low level; The levels of the criteria such as Presence of text, Structuring and systematization, Correspondence between headline and main text, Absence of obvious 
grammatical and stylistic errors, Text color variety, Graphics color harmony, Color diversity, Color balance, Presence of illustrations, A rational number of illustrations relative to text, Standardization of illustrations are considered as high; the other indicators are at the average level.

\section{Table 1}

The results of the quality definition of graphic and text publications before and after the declaration of the state of emergency in Ukraine (Shmatkov, 2021)

\begin{tabular}{lccc}
\hline \multicolumn{1}{c}{ Text parameters, \% } & $\begin{array}{c}\text { Mean } \\
\text { (before) }\end{array}$ & $\begin{array}{c}\text { Mean } \\
\text { (after) }\end{array}$ & $\begin{array}{c}\text { General } \\
\text { weighted mean }\end{array}$ \\
\hline Presence of text & 100.0 & 100.0 & 100.0 \\
Didactic reduction & 52.4 & 51.9 & 52.1 \\
Readability & 56.7 & 64.0 & 60.8 \\
Call to action & 61.3 & 40.7 & 49.7 \\
Emphasis & 47.0 & 26.2 & 35.3 \\
Structuring and systematization & 82.3 & 79.3 & 80.6 \\
Correspondence between headline and main text & 78.0 & 66.0 & 71.2 \\
Absence of obvious grammatical and stylistic errors & 93.6 & 99.2 & 96.8 \\
Text color variety & 93.2 & 99.5 & 96.7 \\
Absence of non-clickable links & 47.7 & 64.5 & 57.2 \\
\hline \multicolumn{1}{c}{ Graphical parameters, \% } & & & \\
\hline Graphics color harmony & 73.4 & 69.6 & 71.2 \\
Color diversity & 91.5 & 95.7 & 93.9 \\
Color balance & 90.0 & 90.2 & 90.1 \\
Presence of interactive graphic links & 18.5 & 3.8 & 10.1 \\
Presence of illustrations & 87.2 & 95.5 & 91,9 \\
Rational correspondence between illustration and text & 44.1 & 65.4 & 56.2 \\
proportions & 40.0 & 52.3 & 47.0 \\
Understandability of illustration message without text & 79.3 & 83.3 & 81.6 \\
A rational number of illustrations relative to text & 56.9 & 62.9 & 60.3 \\
Correspondence between headline and illustration & 81.3 & 85.8 & 83.8 \\
Standardization of illustrations & & & \\
\hline
\end{tabular}

Kendall rank correlation coefficient of the expert assessments, $\tau=0.73$. Taking into account large data sets (2600 and 3360 assessments), we used statistical evaluation to confirm the reliability of the results. The distribution of all the assessments for each object and each criterion and the average assessments is particular to the normal distribution (Figs. 1, 2), which is confirmed by high values of $\chi^{2}$. 


\section{Figure 1}

Distribution of the average values of assessments conducted before the declaration of the state of emergency in Ukraine

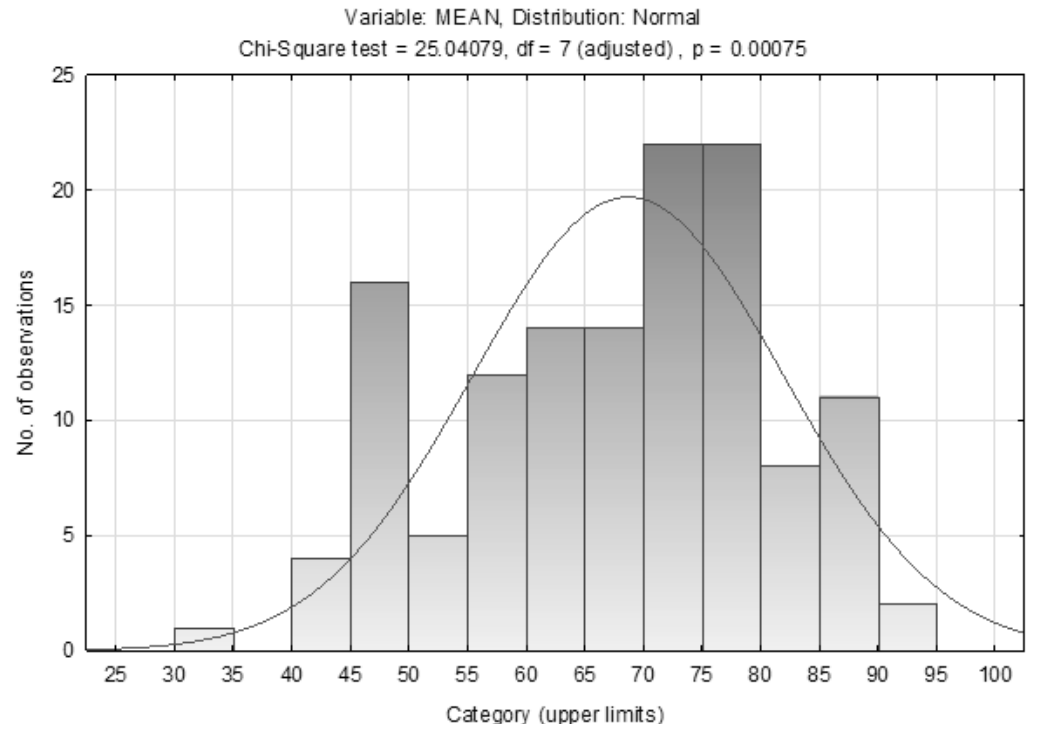

\section{Figure 2}

Distribution of the average values of assessments conducted after the declaration of the state of emergency in Ukraine

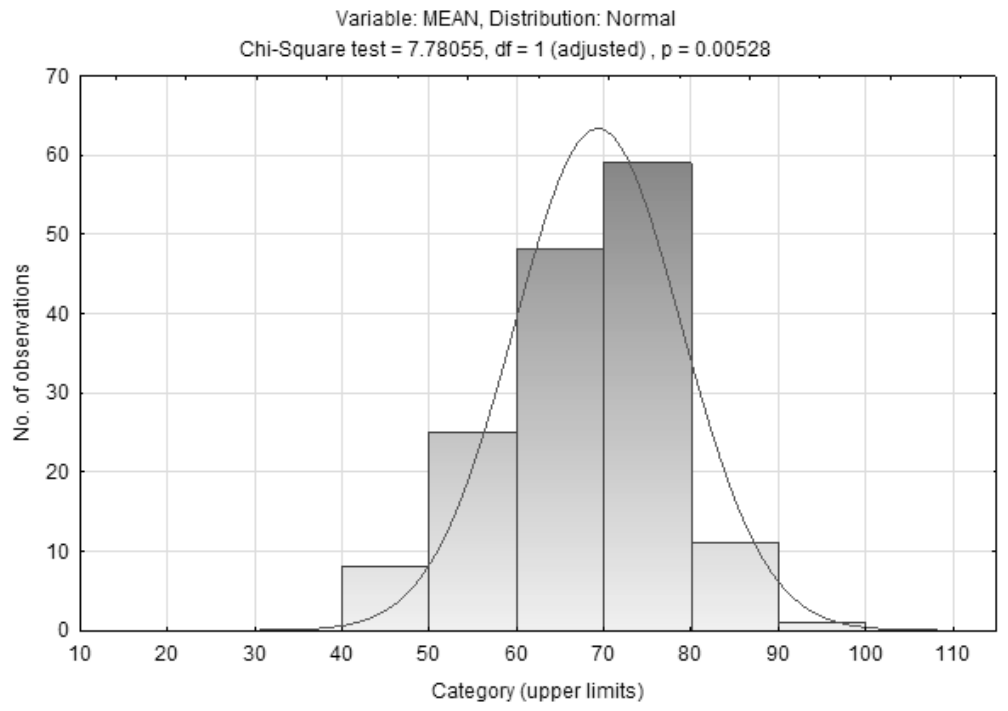

Therefore, the results of the study are statistically defensible. 


\section{Discussions}

In the process of analyzing the scope diagrams to identify the criteria by which the smallest and the greatest spread of expert assessments for all three organizations was observed, we have determined the following.

Prior to the declaration of the state of emergency in Ukraine, the lowest range of the assessments was displayed by the following criteria: Presence of text; Text color variety; Absence of obvious grammatical and stylistic errors. The assessments by other criteria were medium or large. After the declaration of the state of emergency, the lowest range of the assessments was displayed by the following criteria: Presence of text; Absence of obvious grammatical and stylistic errors; Text color variety; Graphics color harmony. This fact indicates that the approach and opinions of the experts in evaluating publications based on these criteria before and after quarantine practically did not change, and the publications themselves are more unified by the above-mentioned criteria than by the rest.

We did not identify significant changes in the quality of publications after the declaration of the state of emergency in Ukraine: the decrease in quality by Text parameters accounted for $2.2 \%$, the increase in quality by Graphic parameters $-4.4 \%$. We believe that such little differences may not exceed the accuracy of the expert assessment. Due to the lack of a more statistically significant difference, it is necessary to conclude that the overall quality of posters has not changed depending on the situation in Ukraine. In part, this may be due to the fact that the organization such as WHO is likely to publish the same posters in different languages in different countries, where severe restrictive measures were imposed at different periods of time. We also assume that the creators of the posters did not have the opportunity or did not consider it necessary to improve the quality of posters after the introduction of quarantine restrictions.

It should be noted that before the declaration of the state of emergency in Ukraine, among the text parameters, the lowest range of assessments was displayed by the criteria such as "Emphasis", "Absence of non-clickable links", "Didactic reduction", and "Readability". The need to adhere to the quality criterion "Absence of non-clickable 
links" comes from the user experience and aims to improve interaction with the publication. Ensuring effective distribution of content, as well as accelerating access to key aspects by means of the criterion "Emphasis" directly reduce the cognitive load of the user and increase perception efficiency of the information obtained (Prajayanti et al., 2015; Shmatkov, 2016). Font size, in turn, also affects the acceleration of access to key aspects and ensures the formation of more profound interpretations (Yang, Huang \& Shanks, 2018). Therefore, these aspects should not be neglected during the development of educational and information posters.

The posters published after the declaration of the state of emergency in Ukraine are characterized by the lowest range of assessments on the following criteria: "Emphasis"; "Call to action"; "Didactic reduction". All these aspects affect convenience and speed of handling the information, understanding the basic message and effective implementation of actions (Rahman \& Amri, 2019).

Among the graphical parameters of the analyzed publications which had been made before March 25, 2020, the lowest assessments were given to the following: "Presence of interactive graphic links"; "Understandability of illustration message without text"; "Rational correspondence between illustration and text proportions". Given the moderate general weighted mean $(57.2 \%)$ of the absence of nonclickable links, low availability of active graphic links becomes even more urgent in terms of ensuring user interactivity with information. As for ensuring a rational correspondence between illustrations and text block, as well as understanding the message of the illustration without text - these measures are aimed at ensuring the transfer of information to people of all intellectual abilities, education, age, etc. through the specific nature of sensory perception (Ware, 2019). Therefore, each of these elements is important in the projection of accelerating the functioning of psychological processes. After March 25, 2020, the situation with the Graphical parameters of the published posters partially changed - the criterion of rational correspondence between illustration and text proportions was improved by the creators.

Comparing the quality of publications before and after the declaration of the state of emergency in Ukraine, we have revealed the following. The largest increase $(21.3 \%)$ in terms of quality was made according to the mentioned criterion "Rational correspondence between 
illustration and text proportions". It is quite obvious that when scrolling through the news feed on Facebook, an individual will first pay attention to the illustrations, not the text, and will continue to decide whether to stop to read the post. The quality of the criteria such as "Call to action" and "Emphasis" (> 20\%) decreased the most. However, it would be logical to assume that, due to the imposed strict quarantine restrictions, the language of the official organizations responsible for public health should have become clearer and more directive.

The analysis of the relationship between the sequence of publications and the quality of the mentioned parameters with the largest changes did not establish any. Therefore, most likely, the changes were random and were not planned in advance by the creators. In the course of the research, we also carried out a correlation analysis between the frequency of publication of all posters and their overall quality in order to establish quality trends over time. Given that the correlation coefficients were $r \leq|0.41|$, no regularities were established.

As a result of the study, a number of positive and negative practices were identified.

All the posters contained some text, which allows the user to understand in detail the main message of the poster. However, these texts quite often contained background information that could be edited or removed. Given the space constraints of such a means of transmitting information, didactic reduction is an adequate method of conveying the idea to the user with minimal losses (Krüger \& Mannebach, 2019). Strict design and didactic reduction provide orientation in the jungle of information (Hörler, Silic \& Pahr-Gold, 2020). Most of the posters were quite easy to read due to the adequate font size. However, on some posters the text could not be seen at all, so the question arises as to whether it is appropriate to use the text size, which a healthy user needs to zoom in order to be able to read.

We did not assess the posters that contained only statistics data on the spread of the virus and announcements. The content of the posters under consideration was to educate the public and shape appropriate behavior of individuals before and during the Covid-19 outbreak. Psycholinguists argue that emotional overtones have a definite meaning from the point of view of memory and perception (Cortese, Khanna \& Hacker, 2010; Kensinger \& Corkin, 2003) as well as in terms of effectiveness of crisis response (Figueiredo et al., 2020). Therefore, 
in our opinion, the low value of the "Call to action" criterion should be eliminated in subsequent publications to ensure the directive voice (Rahman \& Amri, 2019) of the officials. Emphasis placement is used to a very limited extent by the poster developers, although this tool is both a good guide and a mean of attracting the user's attention.

Close in function to the emphasis is the headline. When focusing on a particular publication, the user expects to find a more detailed disclosure of the headline in the text. Inconsistency between headline and main text can lead to some frustration and misinterpretation. "Misleading headlines affect readers' memory, their logical reasoning and behavioral intentions" (Ecker et al., 2014). In addition, over the past several decades, much has been discovered regarding how the psycholinguistic properties of words affect cognitive processes in human brain (Paetzold \& Specia, 2016). High level of correspondence between image and text facilitates conceptual message handling (Luna \& Peracchio, 2001). Therefore, this indicator should also be improved.

The criterion "Absence of obvious grammatical and stylistic errors" is at a high level, that influences a high rate of text recognition (Altmann, 2001) and trust. Although several publications had minor inaccuracies, this could well affect the fact that readers could perceive posters with grammatical errors "to be lower in quality, credibility, and informativeness" (Appelman \& Schmierbach, 2018). The criterion "Text color variety" is also at a high level, which greatly simplifies the perception of information in the absence of the need to shift attention among varieties of text colors.

The criterion "Absence of non-clickable links" did not show a good result. On the one hand, the inexpediency of presenting non-clickable website addresses on posters from the point of view of providing interactivity is obvious. On the other hand, our opinions were somewhat divided on the issue of the appropriateness of presenting hash tags on posters. Psycholinguistic studies show that the authenticity of texts can provide additional interpretations (Figueiredo et al., 2020). The main function of a hash tag is to search for or combine news into a group, which is impossible to do by clicking on the picture. At the same time, by showing the names of the hash tags on the posters, the designer makes it clear to the user that such a hash tag does exist and is important. Although, in this context, what is the point of displaying 
a hash tag such as \#Covid-19 (which is already mentioned in the heading and underlined in the main text, and it is likely that the user will guess to enter this hash tag before reading the poster)? Thus, the designer wastes useful poster space on duplicating information that does not carry significant semantic load. This issue is debatable, but in our evaluations, we are inclined to believe that the use of obvious hash tags on posters is not a good practice.

Despite the difficulty of holding a certain amount of important information, the vast majority of publications have a clear structure. This aspect simplifies content navigation and improves the quality of reviewed posters.

The number of psycholinguistic studies with the use of colored stimuli is constantly increasing (Moreno-Martínez, Montoro \& Laws, 2011). Color diversity and color balance in the terminology of this study are kept at a high level. Graphics color harmony did not always meet the requirement of maintaining the contrast of the graphics.

The designers practically do not use interactive graphic links such as QR codes, although their relevance in the formation of communication is emphasized by scientific studies (Shin, Jung \& Chang, 2012) and also their presence enables readers to go directly to the resource that contains more detailed information. Perhaps QR codes are not a convenient tool for each user, but they are active, unlike links and hash tags. The developers of about 30 posters analyzed agree with us and have placed interactive graphic links on their creative works which were analyzed by us.

One of the consequences of the high interest in images and other forms of mnemonics was a huge increase in the use of intelligent linguistic materials in associative learning research (Johnson-Laird, 1974). Presence of illustrations on posters significantly simplifies perception of the key message (Ware, 2019). According to this criterion, the reviewed publications were highly rated. However, placing an illustration on a poster is not enough to understand it. It is necessary to ensure rational correspondence between illustration and text proportions and understandability of illustration message without text - according to these criteria the posters did not score high points. We were faced with the fact that several posters with different text content had the same illustrations, which just in one of several cases were adequate to the text. This is also confirmed by the low value of the criterion "Correspondence 
between headline and illustration". Reducing the time for developing a poster in this way, the designer, in our opinion, can cause the abovementioned slowdowns in the user's mental processes - memory, inferential reasoning, and behavioral intentions (Ecker et al., 2014). This thesis is confirmed, for example, by the fact that users integrate information from a headline with an image, and inconsistencies cause a slowdown in cognitive processes (Chen, Conroy \& Rubin, 2015).

In the analysis presented, we highly rated the posters according to the "Standardization of illustrations" criterion. Most of them have clear associative links that will be correctly interpreted in different cultures, for example, a person, a pill, a plane or a house.

\section{Limitations}

One of the limitations is the inherent equivalence of each criterion for the general assessment. The level of impact of each variable on improving citizen instruction may be the goal for further research. Psycholinguistic variable such as word frequency is not considered in this study in the context of studying similar creolized texts, but may also be an object of future research. Also, one of the limitations is the chosen research method - expert assessment. However, given the large number of assessments that would have to be carried out (5960) as a result of, for instance, interviewing a group of respondents without or with low level of the expertise, using an expert assessment method is a more adequate and feasible approach in this case.

In general, the evaluation system used, according to the authors, provides an objective assessment of graphic-text web publications. Firstly, the justified parameters reflect the state of the art. The current list is based on scientific literature on user experience in the light of psycholinguistics, psychology, pedagogy, information technology, etc. Secondly, the current list of parameters is supported by positive experience of the experts. In addition, it should be noted that, in our opinion, an increase in the number of parameters could lead to an increase in the subjectivity of the assessment due to the fact that creative activity of the authors of publications is mostly evaluated. A decrease in the volume of parameters may be accompanied by an artificial decrease or increase in the averages on the criteria. 


\section{Conclusions}

As follows from the "Research Context" and "Results" sections, psycholinguistic variables such as readability, imageability, concreteness, conceptual familiarity, semantic size, name agreement, image agreement, visual complexity, typicality, image variability, text authenticity, processing fluency etc. in various forms and interpretations penetrate deeply important related research on the creolized texts which were analyzed. Given the specifics of the study, an impact of variables such as arousal, dominance, valence, word frequency, age of acquisition, and gender association on the presented results was not theoretically identified. It is important to note that the subjective perception of one or another creolized text is influenced not only by linguistic characteristics, but also by a large number of extralinguistic factors (Lebedeva \& Annenkova, 2018).

Using the above variables in various forms and interpretations in the study, we revealed that the quality of the posters on Facebook made by official institutions operating in the field of health care is at the borderline between medium and high levels and accounts for $69.3 \%$. In terms of text parameters this figure is $70.0 \%$, and in terms of graphics $-68.6 \%$. Given these estimates, as well as the particular importance of quality public information, these indicators are most in need of improvement on text parameters such as "Emphasis" and "Call to action", as well as on graphical parameters such as "Presence of interactive graphic links" and "Understandability of illustration message without text".

The results of the study confirm the fact that the posters (especially those used in the field of public health and safety) can be characterized by maximum didactic reduction (Krüger \& Mannebach, 2019) to reduce the cognitive load of users. Also, we complemented the studies devoted to the issues of increasing interactivity of the use of web publications and improving the efficiency of higher mental processes through the Internet of Things (Gao, Liu \& Paas, 2016; Shin, Jung \& Chang, 2012). We also stated the fact that currently national and international institutions prefer to place inactive links in graphic and text publications.

In the digital age, educational and informational posters published on social networks are an effective means of communication, influence, reducing panic, raising awareness and more. Therefore, such publications 
should be characterized by a high level of trust, simplicity of use, speed and reliability of transmission of relevant information alongside with wide range of opportunities to influence the population.

This study confirms that the theory of psycholinguistics can be applied in a variety of interdisciplinary contexts (Speed, Wnuk \& Majid, 2018). The results of the study can be used as one component of many important and effective efforts to overcome the global crisis associated with the Covid-19 pandemic and mitigate its effects.

In addition to the above-mentioned aspects, further research is needed to study the quality of the widespread video content, as well as the psycholinguistic features of the impact of media publications on the population.

\section{References}

Ali, A.Z.M., Wahid, R., Samsudin, K., \& Idris, M.Z. (2013). Reading on the Computer Screen: Does Font Type Have Effects on Web Text Readability? International Education Studies, 6(3), 26-35. https://doi.org/10.5539/ies.v6n3p26

Altmann, G.T. (2001). The language machine: Psycholinguistics in review. British Journal of Psychology, 92(1), 129-170. https://doi.org/10.1348/000712601162130

Appelman, A., \& Schmierbach, M. (2018). Make no mistake? Exploring cognitive and perceptual effects of grammatical errors in news articles. Journalism \& Mass Communication Quarterly, 95(4), 930-947. https://doi. org/10.1177/1077699017736040

Bavel, J.J.V., Baicker, K., Boggio, P.S. et al. (2020). Using social and behavioural science to support COVID-19 pandemic response. Nature Human Behaviour, 4, 460-471. https://doi.org/10.1038/s41562-020-0884-z

Berger, J., Humphreys, A., Ludwig, S., Moe, W.W., Netzer, O., \& Schweidel, D.A. (2020). Uniting the tribes: Using text for marketing insight. Journal of Marketing, 84(1), 1-25. https://doi.org/10.1177/0022242919873106

Biran, O., Brody, S., \& Elhadad, N. (2011). Putting it simply: a context-aware approach to lexical simplification. The Proceedings of the 49th Annual Meeting of the Association for Computational Linguistics: Human Language Technologies: Short papers (Vol. 2, pp. 496-501). Association for Computational Linguistics.

Blinnikova, I., \& Ishmuratova, Y. (2019). Analiz kognitivnoj kompetentnosti specialistov himicheskoj otrasli na osnove sravnenija dvizhenij glaz $u$ nachinajushih i opytnyh professionalov [Analysis of cognitive competence of chemists: Comparison between novices and professionals using eye tracker]. Organizacionnaja psihologija - Organizational Psychology, 9(1), 13-18.

Bonin, P., Peereman, R., Malardier, N., Méot, A., \& Chalard, M. (2003). A new set of 299 pictures for psycholinguistic studies: French norms for name agreement, image agreement, conceptual familiarity, visual complexity, image variability, age of acquisition, and naming latencies. Behavior Research Methods, Instruments, \& Computers, 35(1), 158-167. https://doi.org/10.3758/BF03195507

(C) Shmatkov D., Zagalaz-Sánchez M. L. \& Cachón-Zagalaz J. 
Chan, A., Nickson, C.P., Rudolph, J.W., Lee, A., \& Joynt, G.M. (2020). Social media for rapid knowledge dissemination: early experience from the COVID-19 pandemic. Anaesthesia, 75(12), 1579-1582. https://doi.org/10.1111/anae.15057

Chen, Y., Conroy, N.J., \& Rubin, V.L. (2015). Misleading online content: Recognizing clickbait as "false news". In Mohamed Abouelenien, Mihai Burzo, Rada Mihalcea, \& Verónica Pérez-Rosas (Eds.), Proceedings of the 2015 ACM on Workshop on Multimodal Deception Detection (13 th November 2015, Seattle, Washington, USA) (pp. 15-19). The Association for Computing Machinery. New York. NY. https://doi.org/10.1145/2823465.2823467

Cinelli, M., Quattrociocchi, W., Galeazzi, A., Valensise, C.M., Brugnoli, E., Schmidt, A.L., ... \& Scala, A. (2020). The Covid-19 social media infodemic. Scientific Reports, 10(1), 1-10. https://doi.org/10.1038/s41598-020-73510-5

Cortese, M.J., Khanna, M.M., \& Hacker, S. (2010). Recognition memory for 2,578 monosyllabic words. Memory, 18(6), 595-609. https://doi.org/10.1080/09658211. 2010.493892

Cutler, A. (Ed.). (2017). Twenty-first century psycholinguistics: Four cornerstones. Routledge.

Debernardis, S., Fiorentino, M., Gattullo, M., Monno, G., \& Uva, A.E. (2013). Text readability in head-worn displays: Color and style optimization in video versus optical see-through devices. IEEE Transactions on Visualization and Computer Graphics, 20(1), 125-139. January 2014, https://doi.org/10.1109/TVCG.2013.86

Ecker, U.K.H., Lewandowsky, S., Chang, E.P., \& Pillai, R. (2014). The effects of subtle misinformation in news headlines. Journal of Experimental Psychology: Applied, 20(4), 323-335. https://doi.org/10.1037/xap0000028

Enochson, K., \& Culbertson, J. (2015). Collecting psycholinguistic response time data using Amazon Mechanical Turk. PloS One, 10(3), Article e0116946. https://doi. org/10.1371/journal.pone.0116946

Evlanov, L.G., \& Kutuzov, V.A. (1978). Jekspertnye ocenki v upravlenii [Expert Assessment in Management]. Moscow: Economy.

Ferris, K., \& Zhang, S. (2016). A framework for selecting and optimizing color scheme in web design. In Tung X. Bui, \& Ralph H. Sprague, Jr. (Eds.), Proceedings of the 49th Hawaii International Conference on System Sciences (HICSS) (5-8 th January 2016, Koloa, HI, USA) (pp. 532-541). IEEE. https://doi.org/10.1109/ HICSS.2016.73

Figueiredo, S., Soares, A., Vieira, N., \& Devezas, M. (2020). A psycholinguistic analysis of world leaders? Discourses concerning the COVID-19 context: Authenticity and emotional tone. International Journal of Social Sciences, 9(2), 66-69. https://doi.org/10.20472/SS2020.9.2.004

Gao, J., Zheng, P., Jia, Y., Chen, H., Mao, Y., Chen S. et al. (2020). Mental health problems and social media exposure during COVID-19 outbreak. PLoS One, 15(4), Article e0231924. https://doi.org/10.1371/journal.pone.0231924

Gao, Y., Liu, T.-C., \& Paas, F. (2016). Effects of mode of target task selection on learning about plants in a mobile learning environment: Effortful manual selection versus effortless QR-code selection. Journal of Educational Psychology, 108(5), 694-704. https://doi.org/10.1037/edu0000080

Garrett, L. (2020). COVID-19: the medium is the message. The Lancet, 395(10228), 942-943. https://doi.org/10.1016/S0140-6736(20)30600-0

Ghasisin, L., Yadegari, F., Rahgozar, M., Nazari, A., \& Rastegarianzade, N. (2015). A new set of 272 pictures for psycholinguistic studies: Persian norms for name 
agreement, image agreement, conceptual familiarity, visual complexity, and age of acquisition. Behavior Research Methods, 47(4), 1148-1158. https://doi. org/10.3758/s13428-014-0537-0

Grobelny, J., \& Michalski, R. (2015). The role of background color, interletter spacing, and font size on preferences in the digital presentation of a product. Computers in Human Behavior, 43, 85-100. https://doi.org/10.1016/j.chb.2014.10.036

Herdağdelen, A., \& Marelli, M. (2017). Social media and language processing: How Facebook and Twitter provide the best frequency estimates for studying word recognition. Cognitive Science, 41(4), 976-995. https://doi.org/10.1111/cogs.12392

Hopman, J., Allegranzi, B., \& Mehtar, S. (2020). Managing COVID-19 in Low-and Middle-Income Countries. JAMA, 323(16), 1549-1550. https://doi.org/10.1001/ jama.2020.4169

Hörler, D., Silic, S., \& Pahr-Gold, P. (2020). Erfolgreicher Wissenstransfer im Beratungskontext Sozialer Arbeit mit Hilfe von Wissensplattformen. Ein Praxisprojekt im Masterstudiengang Angewandtes Wissensmanagement der $\mathrm{FH}$ Burgenland. Soziales_kapital, 23, 169-174.

Johnson-Laird, P.N. (1974). Experimental psycholinguistics. Annual Review of Psychology, 25(1), 135-160. https://doi.org/10.1146/annurev.ps.25.020174.001031

Kastner, M.A., Ide, I., Kawanishi, Y., Hirayama, T., Deguchi, D., \& Murase, H. (2020). Browsing Visual Sentiment Datasets Using Psycholinguistic Groundings. In Yong Man, RoWen-Huang Cheng, Junmo Kim, Wei-Ta Chu, Peng Cui, Jung-Woo Choi, Min-Chun Hu, Wesley De Neve (Eds.), Proceedings of the Advances in MultiMedia Modeling (MMM'2020): $26^{\text {th }}$ International Conference on MultiMedia Modeling (January 5-8, 2020, Daejeon, Korea). (Part I, Vol. 11962: Lecture Notes in Computer Science), (pp. 697-702). Springer, Cham.

Kensinger, E.A., \& Corkin, S. (2003). Memory enhancement for emotional words: Are emotional words more vividly remembered than neutral words? Memory \& Cognition, 31(8), 1169-1180. https://doi.org/10.3758/BF03195800

Kobayashi, M. (2009). Studies on the Exterior Color of Shops: Effect on the Motives for Entering Boutiques. Osaka Shoin Women's University Proceeding, 46, $121-131$.

Krüger, L., \& Mannebach, T. (2019). One Minute Wonder zielgerecht gestalten. Padua, 14(4), 239-243. https://doi.org/10.1024/1861-6186/a000508

La, V.P., Pham, T.H., Ho, M.T., Nguyen, M.H., P. Nguyen, K.L., Vuong, T.T., ... \& Vuong, Q.H. (2020). Policy Response, Social Media and Science Journalism for the Sustainability of the Public Health System Amid the COVID-19 Outbreak: The Vietnam Lessons. Sustainability, 12(7), Article 2931. https://doi.org/10.3390/ su12072931

Laws, K.R., \& Hunter, M.Z. (2006). The impact of colour, spatial resolution, presentation speed on category naming. Brain \& Cognition, 62, 89-97. https:// doi.org/10.1016/j.bandc.2006.03.002

Lebedeva, S.V., \& Annenkova, A.V. (2018). Psycholinguistic Research of Creolized Advertising Texts: Age Factor. In S. Cindori, O. Larouk, E.Yu. Malushko, L.N. Rebrina, \& N.L. Shamne (Eds.), Proceedings of the $8^{\text {th }}$ International Scientific and Practical Conference "Current Issues of Linguistics and Didactics: The Interdisciplinary Approach in Humanities and Social Sciences" (CILDIAN 2018) (23-28 April 2018, Volgograd, Russia). Series SHS Web of Conferences (Volume 50, No 1), Article 01027). EDP Sciences. https://doi.org/10.1051/ shsconf/20185001027 
Lendzian, H., \& Körner, H. (2018). Finanzanalyse eines Klimaschutzprojektes. In Greefrath, G., \& Siller, H.S. (Eds), Digitale Werkzeuge, Simulationen und mathematisches Modellieren. Realitätsbezüge im Mathematikunterricht (pp. 183203). Springer Spektrum, Wiesbaden. https://doi.org/10.1007/978-3-658-21940-6_9

Luna, D., \& Peracchio, L.A. (2001). Moderators of language effects in advertising to bilinguals: A psycholinguistic approach. Journal of Consumer Research, 28(2), 284-295. https://doi.org/10.1086/322903

Maier, V., \& Budke, A. (2016). The use of planning in English and German (NRW) geography school textbooks. Review of International Geographical Education Online, 6(1), 8-31.

Mohammadi, H., \& Khasteh, S.H. (2019). Text as environment: A deep reinforcement learning text readability assessment model. arXiv preprint arXiv:1912.05957

Moreno-Martínez, F.J., Montoro, P.R., \& Laws, K.R. (2011). A set of high quality colour images with Spanish norms for seven relevant psycholinguistic variables: The Nombela naming test. Aging, Neuropsychology, and Cognition, 18(3), 293327. https://doi.org/10.1080/13825585.2010.540849

Oliva, A., \& Schyns, P. (2000). Diagnostic colors mediate scene recognition. Cognitive Psychology, 41, 176-210. https://doi.org/10.1006/cogp.1999.0728

Paetzold, G., \& Specia, L. (2016). Inferring psycholinguistic properties of words. In Kevin Knight, Ani Nenkova, \& Owen Rambow (Eds.), Proceedings of the NAACL-HLT 2016 Conference of the North American Chapter of the Association for Computational Linguistics: Human Language Technologies (San Diego, California, June 12-17, 2016) (pp. 435-440). Association for Computational Linguistics.

Percy, L. (1992). Thoughts on the Importance of Psycholinguistics to the Understanding of Effective Advertising Communication. In John F. Sherry, Jr. and Brian Sternthal (Eds.), NA - Advances in Consumer Research (Vol. 19, pp. 268-269). UT: Association for Consumer Research

Prajayanti, S.S.R., Hidayat, T., \& Rahmat, A. (2015). Didactical reduction of teaching materials of spermatophytes to make easier on information processing and to reduce mental effort of senior high school student. In Seminar Nasional XII Pendidikan Biologi FKIP UNS 2015 (Surakarta, Indonesia, November 2015). (Vol. 12, No 1), pp. 175-179). Sebelas Maret University

Purohit, H., Dong, G., Shalin, V., Thirunarayan, K., \& Sheth, A. (2015). Intent classification of short-text on social media. In Xingang Liu, Robert Hsu, Peicheng Wang, Feng Xia, Yufeng Wang, Mianxiong Dong, \& Yuhui Deng (Eds.), Proceedings of the IEEE International Conference on Smart City / SocialCom / Sustaincom (SmartCity 2015) (December 19-21 2015, Chengdu, China) (pp. 222-228). Los Alamitos, California, Washington; Tokyo. https://doi.org/10.1109/SmartCity.2015.75

Qiu, Q., Luo, X., Watanabe, S., \& Omura, K. (2018). Affective Color Theme Generator for Visual-Textual Design: The Exploration of 3-Color for Banner Design. The $4^{\text {th }}$ International Symposium on Affective Science and Engineering ISASE' 2018 (May 31, 2018 - June 02, 2018, Eastern Washington University, USA). (Vol. 4, pp. 1-6). https://doi.org/10.5057/isase.2018-C000007

Rahman, F., \& Amri, A. (2019). Design of Denotative and Directive Text Poster as Cognitive Stimulant in Basic Education Institution. Jurnal Desain, 6(01), 61-68. http://dx.doi.org/10.30998/jurnaldesain.v6i01.2327 
Rello, L., Pielot, M., \& Marcos, M.C. (2016). Make it big! The effect of font size and line spacing on online readability. In CHI' 16: The Proceedings of the $2016 \mathrm{CHI}$ Conference on Human Factors in Computing Systems (May 2016) (pp. 36373648). https://doi.org/10.1145/2858036.2858204

Shin, D.H., Jung, J., \& Chang, B.H. (2012). The psychology behind QR codes: User experience perspective. Computers in Human Behavior, 28(4), 1417-1426. https:// doi.org/10.1016/j.chb.2012.03.004

Shmatkov, D. (2016). The use of causal maps as interdisciplinary didactic reduction. Advanced Education, 6, 16-21. https://doi.org/10.20535/2410-8286.74335

Shmatkov, D. (2021). Analysis of Posters for Informing the Population via Social Media during Covid-19: Ukrainian Network, Mendeley Data, V2. https://doi. org/10.17632/xd8h7n9kkc.2

Shmatkov, D., Bielikova, N., Antonenko, N., \& Shelkovyj, A. (2019). Developing an environmental monitoring program based on the principles of didactic reduction. European Journal of Geography, 10(1), 99-116.

Snodgrass, J.G., \& Vanderwart, M. (1980). A Standardized Set of 260 Pictures: Norms for Name Agreement, Image Agreement, Familiarity, and Visual Complexity. Journal of Experimental Psychology: Human Learning \& Memory, 6, 174-215. https://doi.org/10.1037/0278-7393.6.2.174

Speed, L.J., Wnuk, E., \& Majid, A. (2018). Studying psycholinguistics out of the lab. In A. De Groot, \& P. Hagoort (Eds.), Research methods in psycholinguistics and the neurobiology of language: A practical guide (pp. 190-207). Hoboken: Wiley.

Sterling, J., Jost, J.T., \& Bonneau, R. (2020). Political psycholinguistics: A comprehensive analysis of the language habits of liberal and conservative social media users. Journal of personality and social psychology, 118(4), 805834. https://doi.org/10.1037/pspp0000275

Sweller, J., Chandler, P., Tierney, P., \& Cooper, M. (1990). Cognitive load as a factor in the structuring of technical material. Journal of Experimental Psychology: General, 119(2), 176-192. https://doi.org/10.1037/0096-3445.119.2.176

Ware, C. (2019). Information visualization: perception for design. Morgan Kaufmann.

Yang, C., Huang, T.S.T., \& Shanks, D.R. (2018). Perceptual fluency affects judgments of learning: The font size effect. Journal of Memory and Language, 99, 99-110. https://doi.org/10.1016/j.jml.2017.11.005

Zhou, W., Wang, A., Xia, F., Xiao, Y., \& Tang, S. (2020). Effects of media reporting on mitigating spread of COVID-19 in the early phase of the outbreak. Mathematical Biosciences and Engineering, 17(3), 2693-2707. https://doi. org/10.3934/mbe.2020147

\section{АНОТАЦІЯ}

Meта. Дослідження має на меті визначення обсягу включення психолінгвістичних змінних до аналізу якості директивних постерів у соціальних мережах під час Covid-19.

Методи. Методи, що використовуються у дослідженні, включають аналіз відповідної наукової літератури щодо виявлення психолінгвістичних категорій та змінних, що мають значення в контексті представленого дослідження,

(C) Shmatkov D., Zagalaz-Sánchez M. L. \& Cachón-Zagalaz J. 
експертну оцінку якісних параметрів постерів, опублікованих у Facebook офіційними організаціями, методи описової статистики.

Результати. Аналіз 298 унікальних робіт, проведений в україномовному Facebook, показав, що загальна середня якість публікацій знаходиться на межі між середнім та високим рівнями - 69.3\% (за текстовими параметрами 70.0\%, графрічними параметрами - 68.6\%).

Висновки. Дослідження показало, що психолінгвістичні змінні, такі як читабельність, образність, конкретність, концептуальна схожість, семантичний розмір, узгодження, візуальна складність, типовість, швидкість обробки тощо, проникають глибоко у пов'язані дослідження креолізованих текстів в різних формах та тлумаченнях. Якість постерів у Facebook, зроблених офіційними установами, що працюють у сфері охорони здоров'я, знаходиться на межі між середнім та високим рівнями. Ці показники найбільше потребують поліпшення щодо текстових параметрів, таких як "Акцент" та "Заклик до дії", а також таких графічних параметрів, як "Наявність інтерактивних графічних посилань" та "Зрозумілість ілюстрачійного повідомлення без тексту".

Ключові слова: креолізований текст, психолінгвістичні змінні, Covid-19, сочіальні медіа, постери, дидактичне скорочення.

Шматков Даниил, Загалас-Санчес Мария Луиса \& Кашон-Загалас Хавьер. Анализ постеров, которые используются для информирования населения через социальные сети во время Covid-19: Украинская сеть

\section{АННОТАЦИЯ}

Цель. Целью исследования является определение объема включения психолингвистических переменных в анализе качества директивных постеров в социальных сетях во время Covid-19.

методы. Методы, используемые в исследовании, включают анализ соответствующей научной литературы по выявлению психолингвистических категорий и переменных, имеющих значение в контексте представленного исследования, экспертную оценку качественных параметров постеров, опубликованных в Facebook офичиальными организациями, методы описательной статистики.

Результаты. Анализ 298 уникальных работ, проведенный в украиноязычном Facebook, показал, что общее среднее качество публикаций находится на границе между средним и высоким уровнями - 69.3\% (по текстовым параметрам - 70.0\%, по графическим параметрам - 68.6\%).

Выводы. Исследование показало, что психолингвистических переменные, такие как читабельность, образность, конкретность, концептуальное сходство, семантический размер, согласования, визуальная сложность, типичность, беглость обработки и прочие, проникают глубоко в связанные исследования креолизованных текстов в различных формах и толкованиях. Качество постеров в Facebook, сделанных официальными учреждениями, работающими 
Analysis of Posters for Informing the Population via Social Media...

в срере здравоохранения, находится на границе между средним и высоким уровнями. Эти показатели больше нуждающихся в улучшении по текстовым параметрам, таким как “Акцент" и “Призыв к действию”, а также таким графическим параметрам, как "Наличие интерактивных графических ссылок" и "Ясность иллюстрационного сообщения без текста".

Ключевые слова: креолизованный текст, психолингвистические переменные, Covid-19, социальные медиа, постеры, дидактическое сокращение. 